\title{
Click Here: Unsettling Scholarly Writing Practices and Knowledge Representation
}

\author{
GUNITA GUPTA \\ University of British Columbia
}

\begin{abstract}
In fine arts, a diptych usually consists of two paintings that are hinged or bound together to form a single piece that opens like a book. In my interpretation of the form, I have written this paper as a textual diptych. It consists of two halves - each of which provides a slightly different perspective and response to the question: How might scholars work to unsettle conventional practices of academic representation in order to allow for different knowledges and understandings to emerge? Further, I wonder in what ways I might expand how and what I write to include as-yet-unsanctioned thoughts, insights, sources, forms, and habits in order to unsettle conventional academic scholarship. This piece of work is my current contribution to the conversation on what it means to write academically, to represent one's scholarship.
\end{abstract}

\section{Main Page}

In fine arts, a diptych usually consists of two paintings that are hinged or bound together to form a single piece that opens like a book. Using this form as my inspiration, I have written this paper as a textual diptych. Reading left to right, the first half of the diptych may be accessed here. This left-sided half is an online, hypertext work created using Twine; it begins with a piece of poetry about writing. The right side is what you are currently reading. Both halves work together and have been created with as much attention to form as to content. Each half consists of a slightly different perspective and response to the question: How might scholars work to unsettle conventional practices of academic representation in order to allow for different knowledges and understandings to emerge? I invite you, dear reader, to join me in my wondering so that you, too, may interrogate your own beliefs and practices. As such, I encourage you to open both halves on your computer and panel them on your screen or screens, placing the hypertext half on the left and this paper on the right, in order to read and experience the form and content of the entire work concurrently.

In this work ${ }^{1}$ I wonder how I might expand how and what I write to include as-yetunsanctioned thoughts, insights, sources, forms, and habits in order to unsettle conventional academic scholarship. The online half is written in hypertext because I want to disturb notions of the temporal in the reading interface. Western conceptions of time form an integral part of colonization that persists to this day (Smith, 2012), and, in academic writing, are manifested in both how we organize our logical argument as well as how we use language. By writing partly in a hypertext environment, I seek both to disrupt a particular view of time, and to express myself in a way more attuned to how I (and maybe

\footnotetext{
${ }^{1}$ When referring to the entire diptych (both my paper and the online half) as a whole, I will use the noun "work".
} 
you too?) personally experience the world and manifest my understandings - in a cyclical, recursive, disjointed, and reflexive way. In addition, I appreciate the ways in which a hypertext document still allows me to write, but also to play with language, mode, and form in a way that feeds and sustains my writerly self.

If a scholar's academic literacy (Lea \& Street, 2006) has been, until now, measured by our ability to adhere to Western conventions and forms of scholarly expression, the future of a decolonized scholarship (especially in literacy and education) demands that we be attentive to formal considerations for our work and be willing to experiment with nonconventional means of expression and representation that allow us to sound more like ourselves (Marker, 2017). For some, this may very well be a conventional form like the Western academic article, written in English, and following a linear trajectory of rational argument. For others, like me, while I may be able to write in this form, it is not my preferred means of expression. Instead, as I write myself into being, I consider my situation-both the place(s) in which I find myself as well as the "short list of critical positions" (Haraway, 1988, p. 586) I occupy - and how best to honour it, as well as claim to know something.

The hypertext half of this paper is rendered in a way that seeks "to find a passage through the swampy cross-cultural academic terrain of conflicting forms of consciousness" (Marker, 2017, p.7). In my case, my creative consciousness is often in conflict with what is expected of me as an academic. Hyper-text encourages multi-linear reading: reading which may begin at a specified place but can take many different paths depending on what one chooses to click as they go. While detractors might comment that a reader of hypertext may interact with content superficially (e.g. Mangen, 2008) as a result of unsustained attention to a drawn out linear argument, I disagree. I prefer to use hypertext expressly because it allows a reader to choose a path, inviting them to click back and forth, to read and re-read, and to forage for meaning through active interaction with the piece.

Foraging means to search for provisions or resources - food, in the most literal sense, but sustenance to put it more figuratively. All beings forage; foraging is not the province of a single species, society, or civilization. Thus, I use the term "forage" purposely, for what I hope to create when I write in hypertext are virtual trails in a virtual landscape, from which a reader might gain sustenance in the form of knowledge made from connections unforeseen in the making. This foraging poetics, if you will, is a term I use to describe an attention to form and content that refuses a single, linear argument in favour of something more akin to collage: multi-genre/multi-modal representation with multiple entry points, and which draws on a multitude of knowledge sources and works.

In a foraging poetics, as the scholar making scholarship, I do so by foraging from my surroundings, according to my personal ontological and epistemological commitments, anything and everything that feeds me (for example, doing a lit review without constraining my sources to scholarly publications). Less academically, this means that in experiencing the world sensually, I forage for varied and multiple understandings from diverse landscapes. The values of these landscapes and my personal forage are not just determined by the institutions I inhabit; rather, I decide what counts according to my own tastes, preferences, needs, and desires in consideration of the communities of which I am a part, and for whom I work. I then form my understandings into something according to a poetics that aligns as much as possible with all of my tastes, my commitments, and the contents of my foraging. The reader or wanderer/wonderer through the landscape of what 
I create then might do the same, allowing for a cyclical, recursive, reflexive experience of ideas that has the potential to resist the homogenizing influences of dominant ways of being and knowing.

Think of a moment when you have read a novel, and the author describes an event or a sensation in such a way that it seems to resonate with a fundamental aspect of your being. All of a sudden you know and understand something vital-something that, to this point, had only been sensed, but never uttered. Although my example is based on written text, it is hubris to think that only the written word can have such an effect. Indeed, those of us who enjoy music and visual art can easily attest to experiencing this sensation in nonlinguistic ways. How can we possibly expect scholarly knowledge to have truly profound effects on the world if we constrain its communication to a very narrow aspect of a single textual mode? Is this not what got us into this hegemonic mess in the first place?

In a foraging poetics, what is found and who does the finding determines the form representation ultimately takes. Not everything we think might best be communicated in words, and there are also a myriad ways to use words to communicate what we think and know. Attending to the best ways that my thinking and knowing might be represented means becoming attuned to my surroundings, and then making conscious choices regarding my forms of communication with respect to these surroundings. In this case, while I might compose a typical academic paper to say everything I wish to say, I choose, instead, to use a form of expression that respects and responds to my subject, my ontoepistemology, and - in this case - the rules and scope of the journal I have submitted to. By combining a hypertext piece with a quasi-conventional academic paper, I get to write academically (something I enjoy), but I also get to include poetry and images (photography, drawing, and collage) in a way that creates something that more fully represents me in all my onto-epistemological diversity than a conventional academic article.

Poetry, specifically, is a fundamental means by which I understand and communicate what I know and believe about the nature of reality, as it were. While I have learned to use academic language and form to express myself, it is really only in the poetic use of language that I feel completely centered within myself and the world. Hence, as you, the reader, move through the hypertext half of this work, what you will find is a multigenre rendering of the contents of my own foraging - a rendering which, I feel, is much more expressive of my situation as a scholar who-like you, maybe?-embodies many conflicting forms of consciousness. Such expressivity is not to be mistaken for reconciliation in the sense that this work is not seeking to resolve the conflict of my consciousness. Rather, it seeks to bring together the disparate parts in order to form a unified, poietic (Whitehead, 2003) response to my inquiry.

To be clear, I am not calling an end to the written word or the peer-reviewed journal. My intention is not to re-place normative, sanctioned ways of representing scholarship - despite their obvious colonial provenance. Rather, my intention is to promote expansion: to find modes of representation other than what is expected, which both recognize and celebrate the boundlessness of human thought and activity to produce worthwhile knowledge. That said, I do submit that what counts as scholarship might be found in places other than the peer-reviewed academic journal and, therefore, might be present(ed) in places other than the peer-reviewed academic journal. 
This work is my current contribution to the conversation on what it means to write academically, to represent one's scholarship. For the purposes of this paper, I define academic writing and scholarly representation as written textual artifacts produced by academics/scholars (I use the terms interchangeably) seeking to have their ideas "counted" as original contributions to knowledge. While intentions and motivations undoubtedly vary, such scholars create said artifacts (theses, dissertations, articles, monographs, etc.) in hopes that they might be published (made public) — most usually in established academic journals. Though there are notable exceptions, overwhelmingly, scholarly research is represented in a limited number of ways, using standards, rules, and traditions that work only to confine, restrict, and constrain expression.

\section{About}

As a teacher and a writer, I have never been at ease with prescribed forms, even while I believe that familiarity and prowess with prescriptive writing allows one to break convention in unconventional ways. I teach my students that there are many ways to communicate one's ideas, to cook a meal, to tell a story...but that certain ways are upheld as more authentic and powerful-depending on who is looking - and that power determines what is heard. That if you want to say something differently, you must be prepared to fight to say it.

I have lately become more and more preoccupied with expression as I begin doctoral studies and I realize that this role of knowledge-maker is laden with responsibilities to different bodies who often have conflicting stakes in my work.

To my supervisor, I am a charge: my job is to do what is required of me to earn my degree, and to do it well. This includes successfully completing all requirements, applying for funding, and, possibly, publishing.

To the university, I am an investment in the future and a potential feather in their cap, assuming I am able to do what needs to be done.

To my family, students, and colleagues, I am an example; and it is for them that I work to disrupt the norms of academic writing - to work toward an unsettling of what it means to know something and to express that knowing as a part of one's writing. To them I have always been unconventional. I believe that doing this degree conventionally would be hypocritical. And so, I seek ways that allow latitude in conception, action, and representation - especially representation - so that what results is a communication of knowledge that appeals to them first. I write to be read, not by the prevailing powers, but by the people I care about.

Finally, to myself, I am something else entirely. Yes, I am a writer and a poet and a chef. I am a teacher of English and Home Economics in a middle to upper-middle class high school remarkably like the one I attended in the late 80s and early 90s. I am a mother, partner, sister, daughter, and aunt. But I am also becoming something more. As I begin to imagine my place in the knowledge-creation continuum, I ask myself questions I have never before entertained: how will my language and choices support or detract from my imagination of my (future) being? With whom will I find a professional, intellectual community? What do I think and believe, and how do I choose to express and represent this? Will any of this, at all, "count" as scholarship? My questions echo Laurel Richardson's (1997) when she asks: "How, then, do we write ourselves into our texts with intellectual and spiritual integrity? How do we nurture our own voices, our own 
individualities, and at the same time lay claim to 'knowing' something?' (p. 2, emphasis in original).

Various answers have been offered over the past few decades as methodologies have been invented, and work has been done to add to the discourse on what qualifies as representation in scholarship. Most importantly, Indigenous, arts based/arts informed, a/r/tography, decolonizing, feminist, and post-qualitative research methodologies (as well as some combinations of the same) have emerged, giving voice and space - and, claiming authority for-different ways of knowing and understanding the world. What I see in the work of scholars and others who push the envelope, and question the status quo of what counts, is an enduring desire for expansion in the meaning of scholarship, knowledge, and representation (Said, 1994). And so, in my work, I merge my understandings and gleanings from the writings of these and other scholars with my own ways of knowing the world to create forms which pay homage to them and allow me to finally write myself into my work with intellectual and spiritual integrity. In relation to these scholars, I humbly place myself (Dion, 2007).

\section{Settings and Preferences}

In education grounded in Western epistemology, "print literacy" (Hare, 2005, p. 243) dominates a student's and scholar's concerns. We are required to learn to read and write as soon as we enter school as a way of knowing that supersedes many other ways that might be present. When we enter post-secondary and graduate school, the requirement to read and write is only heightened. And a Master's or Doctoral degree is awarded based on the quality of written material produced by the student.

Print is the mode many people imagine when asked where knowledge resides and how knowledge is represented. And for good reason: money. In contemporary times, scholars working within both universities and industry-based research facilities get compensated for their publishing credits in the forms of job promotion, accepted funding grants, and tenure. These publishing credits are very specific, however, and do not (yet) include, for instance, online forms such as self-published websites (Krause, 2007). Steven Krause (2007) writes of online, self-publishing: "This new form of scholarship problematizes the notion of what scholarship is in the sense that it both stretches the boundaries of advancing knowledge and of what should count in an academic career" (online). In his statement, Krause juxtaposes two very different understandings of scholarship: one defined by the institutions in which we work, and one that has as its goal something farther-reaching than job tenure. Scholarship as defined by the academy, while understood in both of these ways, still privileges the advancement of knowledge only as it appears in peer-reviewed academic journals — as research.

The first English research journal was created in 1665 "to improve the dissemination of scholarly knowledge" (Priem, 2013, p. 437). Once one enters academia, what one writes and where one publishes determines their worth as a scholar. Peerreviewed journals with strict guidelines for submission are often the location of choice for academics looking to become known for their scholarship.

Guidelines notwithstanding, in order for a scholar to be published, they must have what Lea and Street (2006) call academic literacy, which "is concerned with meaning making, identity, power, and authority, and foregrounds the institutional nature of what counts as knowledge in any particular academic context" (p. 369). What Lea and Street 
(2006) mean, in simpler terms, is that academic literacy is demonstrated when someone understands and meets the expectations the academy sets. Such expectations in regard to writing may be general (e.g., writing in English), discipline specific (e.g., the use of certain citation systems), or even set by an institution (e.g., publishing frequency). A scholar's fluency in such Discourses (Gee, 1989) determines the extent of one's literacy and confers a corresponding power and authority upon them ${ }^{2}$. Those scholars who are not as fluent, though, or those who wish to change the way things are done, may, then, suffer predictably.

However, there are some who succeed. Over the years, many academics have sought to alter or recreate modes of knowledge creation and representation in ways that still demonstrate a certain academic literacy, but also work to subvert it. These scholars include Indigenous scholars (e.g. Hare, 2001, 2005; Marker, 2016, 2017, 2018; Stewart, 2015), artists and poets (e.g. Dunlop, 1999; Fels, 1999; Irwin, 2003; James \& Leggo, 2017; Prendergast, 2006, 2015; Sameshima, 2007), and proponents of digital media and scholarship (e.g. Ball, 2004; Purdy \& Walker, 2010; Priem 2013). Their work has changed academic scholarship to include the different ways in which people live, learn, make sense, and express ourselves. I ally myself with them as I undertake my own journey to unsettle research practices and academic knowledge representation.

\section{Help}

Jan Hare (2005) writes that Indigenous literacy, "was a matter of learning to read symbols and inscribe meanings across landscapes within the family, which served as the primary medium of cultural continuity and the context for their literacy experiences" ( $p$. 245). Indigenous knowing, according to Hare, is a literacy of body, family, culture, and place. However, such literacy was effectively deemed insignificant at the time of colonization. Instead, a very narrow definition of valid ways of being and knowing of a civilized society - manifested by very particular qualities and actions - were promoted by colonizers. Linda Tuhiwai Smith (2012) writes that "one of the supposed characteristics of primitive peoples was that we could not use our minds or intellects [...] By lacking such virtues we disqualified ourselves, not just from civilization but from humanity itself" (p. 26). Because they did not produce written textual artifacts of the kind Western colonizers deemed valuable, Indigenous peoples, as Smith said, were construed as inhuman.

In Canada, the Truth and Reconciliation Commission (TRC), established in 2008, finally made widely public the history of Canadian residential schools and the lasting impact they had on Indigenous survivors and families. As the TRC exposed how colonizers sought to indoctrinate and civilize through forced institutionalized education, cultural genocide, and violence, they forever changed the ways in which Canadians viewed their complicity in the atrocities committed. Some of us now believe that anyone who is a part of settler culture, educated in the very same system that sought to eradicate Indigenous

\footnotetext{
${ }^{2}$ HTTP 400: In response to this point, one of my reviewers provides this feedback: "To be clear: other structural impediments exist despite one's apprehension of academic discourses and fluency therein; and there are some academics who simply cannot write but are still held to be at the top of their fields." Since I am sure the reviewer was not implying that these academics are illiterate, I interpret "cannot write" to mean that these academics cannot write well (whatever that might mean). Nowhere is it stated that writing well is a prerequisite for gaining power. Indeed, the reviewer even mentions "the apparatus of professional editing that props up academic literacy" which actually proves my point, and perhaps suggests that academic literacy even includes recognizing one's limitations, and hiring an editor in order to play the game well, and win.
} 
ways of knowing and being, is implicated in colonialism whenever we uncritically perpetuate the sanctioned practices of a colonial system. Rather than a case of guilt by association, this is a case of guilt by ignorance - which is no longer an option and which the publication of the 94 Calls to Action of the TRC (TRC, 2015) makes sure will no longer be the case.

Ryuko Kubota (2019) also reminds us "to critically examine how our own scholarly activities produce and maintain racial hierarchies and inequalities of different academic knowledges" (p. 4). For me, specifically, such activities include writing and representing in ways predicated on western rhetorical constructs (e.g., rationalism, empiricism, logic, etc.) and forms, as well as ontological and epistemological commitments of western colonial powers. As a secondary teacher and teacher educator, I teach my students to assume a critical stance towards taken-for-granted scholarly norms - such as genres and forms of writing, reading, and representing knowledge - and to take risks with their work as they write themselves into being.

In his piece entitled, "Research as Poetic Rumination: Twenty-Six Ways of Listening to Light," Carl Leggo (1999) ponders his own scholarly writing practice which defies conventional explanation and explication. He writes, "I contend that this essay on research as poetic rumination is scholarly writing, even though it might not always look or sound like the scholarly writing that fills academic journals beyond counting" (Leggo, 1999, p. 116). This quotation is a touchstone for me in my own work and teaching: it comprises the heart of this paper. Carl goes on to define the word scholarship:

Scholar is derived from the Greek schole which signifies 'leisure employed in learning.' In much scholarly writing, "learning" is defined as research, explication, logic, reason, argument, and persuasion. The emphasis is on conclusions, implications, and recommendations. There is frequently a tone of world-weary urgency, akin to a military operation or corporate venture or political strategy convention. In most scholarly writing, learning is not born out of leisure (p.116).

No, Carl, it seems it is born out of something far more calculated and precise: a way of being and knowing that students and scholars, like me, learn (despite what our bodies, families, and relationships teach us) as we make our way through institutionalized education in all its various forms.

I now find myself rejecting this learning, like a body rejects a foreign material, slowly moving it toward the surface until, one day, it simply falls away. My rejection, though, is not a mutiny - an attempt to usurp or undo a tradition which, though built on the backs and sufferings of others, is nevertheless part of a "dominant" narrative and tradition of scholarly work. Rather, as Christine Bridge (2018) puts it, my intention is to contribute to an expansion of a definition of scholarship, which "respects the epistemological and pedagogical foundations provided by both Indigenous ways of knowing and those associated with Western society and formal education" (p. 11), as well as all/any minority ways of knowing and being.

Knowledge comes in many varied forms - not all of which might be rendered in print: "There are many ways to know the world, and the world can only be known in many ways, and even then, only ever known a little" (Leggo, 1999, p. 114). Carl (1999) was learning to listen to light. Indeed, the different ways in which all humans read, experience, respond to, listen to, and tell stories about our immediate surroundings-including and especially light - is what allows for the continued existence of humans on earth 
(Sugiyama, 2001). These are the ontological and epistemological commitments I seek to celebrate in my own work and teaching practice.

\section{Search}

At this point, I invite the reader to follow me down a path: to imagine that all knowledge gained by reading, experiencing, interpreting, and responding to our built, natural, multi-modal, multi-dimensional, and multi-layered surroundings is as valid and vital as that resulting from academic study - more so, even — because this vitally important knowledge knows no bounds, and therefore resists containment in particular, commodified genres, modes, and forms of communication. To think that only academic articles, peerreviewed journals, or university theses - with their colonial means of expression and formal expectations - would ever be enough to give voice to the richness of human understanding seems absurd. What of good walking and talking (Hare, 2005)? Of digital story-telling in web-based media (Jackson, 1997)? What of poetic rumination (Leggo, 1999) braided through with image (Szto, Furman, \& Langer, 2005), sound (Gouzouasis, 2007), and movement (Wiebe and Snowber, 2006)? What of the experience of flavours on the tongue, or the smells (McBride, 2017) of the changing seasons? And what of the language practices that entangle and define our being in the world (Stewart, 2015)?

Yet, many scholars represent their knowledge using particular, commodified genres, modes, and forms of communication in ways, I argue, that subsume their personal ontological and epistemological positions to those of the mainstream academic community. By perpetuating conventional, colonial ways of writing and representing our work, we fail to realize the power we have to change how scholarship might be done and how scholars might be defined. We perpetuate convention to our own detriment and in doing so, make it even more difficult to change. Worse, we continue to do this even while some of us may be deeply troubled by the knowledge that accepted modes of academic communication also serve to ingrain power imbalances and define dominant and nondominant peoples.

Each time a person represents human experience and knowledge in/on/of the landscapes of existence, a self is created and implicated. I propose that, for scholars especially, conventional academic written scholarship may be woefully unable to represent more than a handful of accepted, normative onto-epistemological positions. That, for many of us, something vital is obscured (or lost) when we attempt to fit into predetermined molds of scholarly writing. And, that, for some of us, what is missing is a sense of ourselves. Once again, I quote Laurel Richardson (1997): "How, then, do we write ourselves into our texts with intellectual and spiritual integrity? How do we nurture our own voices, our own individualities, and at the same time lay claim to 'knowing' something?" (p. 2).

As a possible answer, I propose that scholars might work to expand the ways in which we represent knowledge - not just to one another but out into the wider world - to include forms that defy the look and feel of conventional academic treatises. Form must be a key consideration for those wishing to unsettle academic literacy practices. In order to include diverse onto-epistemological positions in the production of knowledge, new ways in which we transmit understandings must be created (or assembled) to fit content, not the other way around, as has been common practice.

As an example, I wrote this paper to explore ways in which scholars might destabilize conventional, colonial forms of academic expression. Had I written this paper 
as a conventional paper with its predetermined, linear, IMRAD-like form, my content, ironically, would have been subsumed to form. But, by choosing to represent my work in the form of a diptych - where one multi-modal, poetic half lives online and one more (or less) conventional half other lives in this journal-I have attempted to do what I propose in this piece: that is, to reconcile the conventions of this journal with both my subject matter and my personal commitments by forming my understandings into a piece that uses a very particular poetics. Earlier I wrote that such poetics must align as much as possible with all of the scholar's tastes, commitments, and contents of their foraging, which necessitates that sometimes some of us will write in singular, unique forms. My hope is that, as we expand the ways in which scholarship is defined, these unique forms will come to count as significant signs of change and contributions to knowledge.

\section{$<$ Previous}

When I first began writing this paper, it was a conference presentation paper-inprogress and, as such, remained unfinished even up until the moment of presentation. In responding to this journal's call for submissions for a special issue based upon conference proceedings, I was compelled to submit a completed paper even though this work (I even hesitate to call it a paper for obvious reasons) actively resists completion as an autotelicor having an end in itself - creation. Put another way, writing/creating this piece of work has been profound as a process, and, as such, I have paid little heed to what it might accomplish once completed and published. Indeed, if I am to be brutally honest, I would have to admit that this has not even been my concern.

In order to be truly dedicated to a project of unsettling academic literacy practices, I feel that I cannot worry myself with what counts as scholarship for my CV or my professional career. And yet, a scholar's work is to contribute to knowledge, and I predicate my argument for unsettling how we do this squarely upon an understanding that this work might serve as an example. CVs and jobs aside, the disruption I seek to exemplify can really only occur if this piece is seen by others-that is, made public, published. Which means, for one, that it is accepted by a journal of some import. And herein lies the problem, for what I have created is a work of active resistance that remains highly critical of epistemological bias in academe, publishing practices of peer-reviewed journals, and scholarly writing as a colonial convention. If a paper could be accused of shooting itself in the foot, this would be the paper!

But let us, for a moment imagine that this paper is accepted and published (and you are currently reading it in a journal), would I, then, be a hypocrite? Does publishing work such as this further implicate me in perpetuating colonial epistemological practices, or does it indicate that things are, in fact, changing? How do we truly unsettle dominant academic writing practices? Or, does the notion of dominance preclude our best attempts at disruption? Above, I wrote that my intention was not to usurp a tradition of scholarly work; however, now, I am not so sure such diplomacy is possible. Joel Kincheloe (2011) writes,

In a counter-colonial move critical ontologists raise questions about any knowledges and ways of knowing that claim universal status. In this context they make use of this suspicion of universalism in combination with global, subjugated, and indigenous knowledges to understand how they have been positioned in the world. Almost all of us from Western backgrounds or non-Western colonized backgrounds have been implicated in some way in the web of universalism. The 
inevitable conflicts that arise from this implication do not have to be resolved immediately. (p. 338)

But they do have to be resolved (or discarded) in order for things to truly change. As I see it, one of the ways to accomplish this is to work within the structures we have created. The academic publishing industry has an immense amount of influence to be a powerful force for change. "What we see and hear in books, journals, or conferences are the results of the decisions to accept or reject certain ideas produced by real people" (Kubota, 2019, p. 17). But just as we need courageous journal editors and publishers, we also need courageous scholars producing and creating research that explicitly questions the universality of Western onto-epistemological practices in academia. Such questions must be posed in form, as well as content. What we choose to research and how we choose to represent our knowledge makes a profound statement about what ways of knowing we support, what ways we challenge, and what ways we reject. Choosing the way(s) that resonate with usrather than unquestioningly perpetuating the status quo of academic writing - means seriously contemplating Laurel Richardson's question of how we approach our work with integrity.

In the online half of this work, you will have experienced one of my attempts to change the structures within which I/we live and work. I have done this by purposefully rejecting linear argument in favour of a mode of writing and representing that privileges the user/reader in making unanticipated connections as she wanders through it, foraging for meaning. "From such interactions emerge a larger whole that is not guided by a central controlling mechanism. Self-awareness of this process of creation may lead to unanticipated modes of learning and new concepts of human being" (Kincheloe, 2011, p. 348). Freeing knowledge creation from the constraints of colonial discourses requires an active commitment to do scholarship differently. Of all the disciplines, language and literacy scholars specifically have the unique ability to use our disciplinary understandings to forage for unanticipated connections and modes of learning. Conducting language and literacy research is already a political statement. Perhaps we might also find different ways of representing our findings that manifest the highly political nature of our work-ways that attend to form as illustrative of content, ways that work to destabilize expected means of knowledge production and mobilization, and ways that illuminate possibilities of a different future for scholarship.

\section{References}

Ball, C. E. (2004). Show, not tell: The value of new media scholarship. Computers and Composition, 21(4), 403-425.

Bridge, C. H. (2018). Land education and reconciliation: exploring educators' practice (Unpublished Doctoral dissertation, University of British Columbia, Vancouver, BC, Canada). Retrieved from https://open.library.ubc.ca/cIRcle/collections/ubctheses/24/items/1.0365284

Dion, S. D. (2007). Disrupting molded images: Identities, responsibilities and relationships - teachers and indigenous subject material. Teaching Education, 18(4), 329-342.

Dunlop, R. (1999). Boundary Bay: A novel as educational research (Doctoral 
dissertation, University of British Columbia, Vancouver, BC, Canada). Retrieved from https://circle.ubc.ca

Fels, L. (1999). In the wind clothes dance on a line: performative inquiry--a (re) search methodology: possibilities and absences within a space-moment of imagining a universe (Doctoral dissertation, University of British Columbia, Vancouver, BC, Canada). Retrieved from https://circle.ubc.ca

Gee, J. P. (1989). Literacy, discourse, and linguistics: Introduction. Journal of education, 171(1), 5-17.

Gouzouasis, P. (2007). Music in an a/r/tographic tonality. Journal of the Canadian Association for Curriculum Studies, 5(2), 33-59.

Haraway, D. (1988). Situated knowledges: The science question in feminism and the privilege of partial perspective. Feminist studies, 14(3), 575-599.

Hare, J. (2001). Aboriginal literacy: Making meaning across three generations in an Anishinaabe community (Unpublished doctoral dissertation). University of British Columbia, Vancouver, BC, Canada. Retrieved from https://open.library.ubc.ca/cIRcle/collections/ubctheses/831/items/1.0055593

Hare, J. (2005). To "know papers": Aboriginal perspectives on literacy. In Anderson, J., Kendrick, M., Rogers, T., \& Smythe, S. (Eds.), Portraits of literacy across families, communities, and schools: Intersections and tensions (pp. 243-263). New York, NY: Routledge.

Irwin, R. L. (2003). Toward an aesthetic of unfolding in/sights through curriculum. Journal of the Canadian Association for Curriculum Studies, 1(2), 63-78.

Jackson, S. (1997). My body: A wunderkammer. Retrieved from http://www.altx.com/thebody/body.html

James, K \& Leggo, C. (2017) Process, remix, juxtaposition, assemblage and selection: How the 21 st century poet makes poetry out of autobiographical material. Axon: Creative Explorations, 7(2). Retrieved from https://axonjournal.com.au/issue-13/poetry-matrix-mother-nature-and-motherboard

Kincheloe, J. L. (2011). Critical ontology and indigenous ways of being: Forging a postcolonial curriculum. In K. Hayes et al. (Eds.) Key works in critical pedagogy (pp. 333-349). Rotterdam, Netherlands: Sense Publishers.

Krause, S. D. (2007). Where do I list this on my CV? Considering the value of selfpublished websites-version 2.0. Kairos: A Journal or Rhetoric, Technology, and Pedagogy, 12(1). Retrieved from http://kairos.technorhetoric.net/12.1/binder.html?topoi/krause/index.html

Kubota, R. (2019). Confronting Epistemological Racism, Decolonizing Scholarly Knowledge: Race and Gender in Applied Linguistics. Applied Linguistics, 1-22. https://doi.org/10.1093/applin/amz033

Lea, M. R., \& Street, B. V. (2006). The" academic literacies" model: Theory and applications. Theory into practice, 45(4), 368-377.

Leggo, C. (1999). Research as poetic rumination: Twenty-six ways of listening to light. The Journal of Educational Thought (JET)/Revue de la Pensée Educative, 33(2), 113-133.

Mangen, A. (2008). Hypertext fiction reading: haptics and immersion. Journal of research in reading, 31(4), 404-419. 
Marker, M. (2016). Indigenous knowledge, indigenous scholars, and narrating scientific selves:"to produce a human being". Cultural Studies of Science Education, 11(2), 477-480.

Marker, M. (2017). Indigenous knowledges, universities, and alluvial zones of paradigm change. Discourse: Studies in the Cultural Politics of Education, 40(4), 1-14. doi:10.1080/01596306.2017.1393398

Marker, M. (2018). There is no place of nature; there is only the nature of place: animate landscapes as methodology for inquiry in the Coast Salish territory. International Journal of Qualitative Studies in Education, 31(6), 453-464.

McBride, M. (2017). Tangible inquiries: A study of aroma materials and sources in the built and botanical environments of Grasses, France. (Unpublished doctoral dissertation). York University, Toronto, ON, Canada. Retrieved from https://yorkspace.library.yorku.ca/xmlui/handle/10315/34467

Prendergast, M. (2006). Found poetry as literature review: Research poems on audience and performance. Qualitative Inquiry, 12(2), 369-388.

Prendergast, M. (2015). Poetic inquiry, 2007-2012: A surrender and catch found poem. Qualitative inquiry, 21(8), 678-685.

Priem, J. (2013). Scholarship: Beyond the paper. Nature, 495(7442), 437-440.

Purdy, J. P., \& Walker, J. R. (2010). Valuing digital scholarship: Exploring the changing realities of intellectual work. Profession, 2010(1), 177-195.

Richardson, L. (1997). Fields of play: Constructing an academic life. New Brunswick, NJ: Rutgers University Press.

Sameshima, P. (2007). Seeing red: A pedagogy of parallax: An epistolary bildungsroman on artful scholarly inquiry. Amherst, NY: Cambria Press.

Smith, L. T. (2012). Decolonizing methodologies: Research and indigenous peoples. London, UK: Zed Books Ltd.

Stewart, P. R. R. (2015). Indigenous architecture through indigenous knowledge: dim sagalts' apkw nisiḿ [together we will build a village] (Unpublished doctoral dissertation). University of British Columbia, Vancouver, BC, Canada. Retrieved from https://open.library.ubc.ca/cIRcle/collections/ubctheses/24/items/1.0167274

Sugiyama, M. S. (2001). Food, foragers, and folklore: The role of narrative in human subsistence. Evolution and Human Behavior, 22(4), 221-240.

Szto, P., Furman, R., \& Langer, C. (2005). Poetry and photography: An exploration into

expressive/creative qualitative research. Qualitative social work, 4(2), 135-156.

Truth and Reconciliation Commission of Canada. (2015). Final report of the Truth and Reconciliation Commission of Canada: Summary : honouring the truth, reconciling for the future. Retrieved from http://www.trc.ca/assets/pdf/Honouring the Truth_Reconciling for the Future July_23_2015.pdf

Whitehead, D. H. (2003). Poiesis and art-making: A way of letting-be. Contemporary aesthetics, 1(1).

Wiebe, S., \& Snowber, C. (2011). The visceral imagination: A fertile space for nontextual knowing. Journal of Curriculum Theorizing, 27(2), 101-113. 


\section{Author Biography}

Gunita Gupta is a teacher in the Langley school district where she has taught mainly English and Foods for the past six years. She has been on the UBC Vancouver campus for most of her life, in one way or another, holds three degrees from this institution, and is currently pursuing her fourth. In her MA, Gunita pondered natality as an existential project of teachers capable of resisting neoliberal forces in education. In her $\mathrm{PhD}$, she is thinking about reconceptualizing food literacy in an effort to de-centre dominant epistemological narratives. Gunita has many varied interests, including (in no particular order) dogs, language, cooking, fiction, exercise physiology, food, history, philosophy, and bikes. She prefers wide open spaces and finds talking about herself in the 3rd person an odd experience. 